\title{
Meningkatkan Motivasi dan hasil belajar IPS Peserta Didik kelas VII-C Semester dua tahun pelajaran 2018/2019 dengan mengoptimalkan penerapan Model Discovery Learning di SMP Negeri 9 Mataram
}

\author{
Mudhofir, S.Pd \\ Guru IPS SMP Negeri 9 Mataram
}

Penelitian ini bertujuan untuk mengetahui efektifitas penerapan pendekatan Saintifik model Discovery Learning dalam upaya meningkatkan motivasi dan hasil belajar IPSPeserta didik kelas VII.CSMP Negeri 9 Mataram. Manfaat penelitian ini adalah mendorong peserta didik untuk mengembangkan ketrampilan belajar dalam kelompok (kognitif) dan bersosiolisasi dengan teman sebagai dalam proses pembelajaran di kelas senyatanya. Dan bagi guru meningkatkan pengembangan pendekatan dan model pembelajaran dengan penerapan saintifik Model discovery learning dalam pembelajaran kerja kelompok (kooperatif). Penelitian ini dilaksanakan dua siklus, masing-masing siklus kegiatannya adalah; perencanaan, pelaksanaan, observasi dan refleksi. Hasil akhir tindakan pada siklus II menunjukkan bahwa hasil observasi guru pada pertemuan kedua memperoleh skor rata-rata $(4,58)$ dan hasil observasi Peserta didik pertemuan kedua mencapai skor rata-rata (4,27). Sedangkan dampak dari peningkatan motivasi belajar adalah meningkatnya perolehan hasil belajar Peserta didik mencapai nilai rata-rata $(92,32)$, artinya indicator keberhasilan $(\geq 4,0)$ dan hasil belajar $(\geq 75,00)$ telah terlampaui. Karena indicator keberhasilan telah terbukti penelitian dinyatakan berhasil dan dihentikan pada siklus II.

\section{Kata Kunci :Motivasi dan hasil Belajar - Pendekatan Saintifik Model Discovery Learning}

\section{PENDAHULUAN}

Kurikulum tahun 2013mengisyaratkan bahwa proses pembelajaran mengacu pada terjadinya interaksi aktif semua peserta didik di kelas selama mengikuti pelajaran dalam bentuk kegiatan nyata untuk mengamati, menanya, mencoba, mengasosiasikan dan mengkomunikasikan serta sedapat mungkin mampu menciptakan, sehingga nuansa pembelajaran peserta didik aktif benar-benar dapat dirasakan secara nyata oleh pemangku kepentingan khususnya guru mata pelajaran dan peserta didik. Pendekatan Saintifik (pendekatan keilmuan) dalam hal ini sangat dibutuhkan dalam melakukan model pembelajaran yang mampu merubah mindset pendidikan yang pada gilirannya proses pembelajaran menjadi bermakna. Kebermaknaan ini merupakan tujuan utama dari kurikulum tahun 2013 (K.13) bagi terwujudnya perilaku peserta didik yang menjadi aktif, inovatif, interaktif, demokratif, dan mampu bersaing dengan teman sejawat adalam proses pembelajaran di kelas senyatanya.

Proses pembelajaran di SMP Negeri 9 Mataram khususnya pada mata pelajaran IPS yang berlaku selama ini masih cenderungnya mengarah pada guru yang aktif menjelaskan materi pelajaran dengan berapi-api tanpa memperdulikan kondisi peserta didiknya.Proses pembelajaran semacam ini telah melahirkan peserta didik yang pasif, kurang kreatif, kurang termotivasi dalam mengingat pelajaran IPS sehingga prosentase keberhasilan pada peserta didik sangat memprihatinkan dan berdampak pada rendahnya tingkat kepercayaan peserta didik terhadap guru IPS dalam proses pembelajaran di kelas senyatanya.

Kondisi nyata yang terjadi pada peserta didik kelas VII-CSMP Negeri 9 Mataram adalah sebagai berikut: 1) peserta didik di kelas ini merupakan penyebaran dari sekolahsekolah yang kualitasnya rendah, 2) peserta didik yang memiliki nilai rata-rata UAS BN pas-pasan, 3) peserta didik yang pada saat proses pembelajaran kurang termotivasi dan cenderung bermain-main, saling lempar buku, keluar masuk kelas tanpa izin, 4) peserta didik yang motivasi belajarnya rendah dan pada saat diadakan ulangan harian memperoleh nilai rata-rata di bawah KKM. Kondisi sebagaimana tersebut diatas dialami pula pada 
proses pembelajaran mata pelajaran IPS. Selama proses pembelajaran peserta didik cenderung tidak peduli terhadap apa yang disampaikan oleh guru mata pelajaran.Ketika guru meminta kepada peserta didik untuk bertanya terhadap materi pelajaran yang disajikan, jika ternyata belum faham, belum mengerti, atau tidak tahu sama sekali semuanya diam, ketika peserta didik di berikan tugas secara berkelompok hanya beberapa orang peserta didik saja yang aktif. Ketika masing-masing kelompok disuruh maju untuk mempresentasikan hasil kerja kelompoknya cenderung tidak bersedia bahkan masing-masing anggota kelompok saling tunjuk yang tidak ada hasilnya.

Faktor penyebab terjadinya situasi kelas yang sangat kurang kondusif dalam proses pembelajaran tersebut adalah berasal dari guru itu sendiri maupun berasal dari peserta didik. Selama ini guru IPS mengajar cenderung mendominasi dengan gaya ceramah yang berapi-api tanpa memperdulikan kondisi peserta didik. Guru IPS sekaligus sebagai peneliti sebenarnya sudah menerapkan pendekatan saintifik sebagaimana yang tertera pada Permen 81 A Tahun 2013 tentang kurikulum 2013, tetapi masih belum optimal dan belum sesuai dengan harapan. Sementara penyebab dari peserta adalah rendahnya kompetensi yang dimiliki serta kurang gairah dalam mengikuti pelajaran IPS. Apapun yang ditugaskan oleh guru, peserta didik nampak cuek dan tidak peduli akan akibat yang akan terjadi pada dirinya.

Banyak solusi yang bisa dilakukan oleh peneliti, tetapi yang dianggap mampu meningkatkan motivasi dan hasil belajar peserta didik kelas VII-C mata pelajaran IPS yaitu dengan mengoptimalkan pendekatan "saintifik" dengan menggunakan Modeldiscovery learning. Pendekatan saintifik ini memiliki keunggulan bila di bandingkan dengan pendekatan yang lain karena proses pembelajaran terdiri atas lima pengalaman belajar pokok yaitu; a) mengamati, b) menanya, c) mengumpulkan informasi, d) mengasosiasi, dan e) mengkomunikasikan. Dalam pengembangan kegiatan pembelajar dengan pendekatan saintifik ini dirancang sebagai berikut; 1) kegiatan pembelajaran disusun untuk dapat melaksanakan proses pembelajaran secara professional, 2) kegiatan pembelajaran memuat rangkaian kegiatan manajerial yang dilakukan guru agar peserta didik dapat melakukan kegiatan seperti di silabus, 3) kegiatan pembelajaran untuk setiap pertemuan merupakan scenario/langkahlangkah guru agar peserta didik aktif belajar. Kegiatan ini diorganisasikan menjadi kegiatan: pendahuluan, inti dan penutup.

Untuk membuktikan bahwa pendekatan saintifik strategi discovery learning dengan model diskusi dapat meningkatkan motivasi dan hasil belajar peserta didikkelas VIICSemester duatahun pelajaran 2018/2019 maka dipandang perlu untuk mengadakan penelitian tindakan kelas (PTK) dengan judul "Meningkatkan Motivasi dan hasil belajar IPS Peserta Didik kelas VII-CSemester duatahun pelajaran 2018/2019 dengan mengoptimalkan penerapan Model discovery learning di SMP Negeri 9 Mataram".

\section{Rumusan Masalah}

"Apakah dengan mengoptimalkan penerapan modelDiscoveryLearning dapat meningkatkan motivasi dan hasil belajar IPS peserta didik kelas VII-CSemester duatahun pelajaran 2018/2019 di SMP Negeri 9 Mataram?"

\section{Tujuan Penelitian}

"untuk mengetahui efektifitas penerapatan modelDiscovery Learning dalam upaya peningkatan motivasi dan hasil belajar IPS peserta didik kelas VII-CSemester duatahun pelajaran 2018/2019 di SMP Negeri 9 Mataram."

\section{Manfaat Penelitian \\ * Bagi Peserta Didik}

1. Mendorong peserta didik untuk mengembangkan ketrampilan belajar dalam kelompok (kognitif) dan bersosiolisasi dengan teman sebagai dalam proses pembelajaran di kelas senyatanya.

2. Motivasi belajar IPS bagi peserta didik dalam upaya pemahaman secara mandiri (eksplorasi) terhadap mata pelajaran IPS sehingga hasil belajar dapat ditingkatkan.

\section{* Bagi Guru IPS}


1. Meningkatkan pengembangan pendekatan dan model pembelajaran dengan penerapan model discovery learning dalam pembelajaran kerja kelompok (kooperatif).

2. Menumbuhkan aspirasi secara ilmiah dalam menjalankan profesi keguruan terutama dalam pengembangan keprofesian berkelanjutan (PKB) bagi guru IPS.

\section{KAJIAN PUSTAKA \\ Motivasi}

Motivasi berasal dari bahasa latin Movere yang berarti dorongan atau daya penggerak. Motivasi adalah daya penggerak yang menciptakan rangsangan belajar seseorang, agar mereka aktif belajar secara efektif dan terintegrasi dengan segala usaha mencapai hasil belajar yang memuaskan.

Menurut Mc. Donald C (dalam Nurhayati;2006) bahwa motivation is a energy change within the person characterizet by affective arraousal and anticipatory goal reactions. Motivasi adalah suatu perubahan energy di dalam pribadi seseorang yang ditandai dengan timbulnya efektif (perasaan) dan reaksi untuk mencapai tujuan.Peserta didik yang memiliki motivasi yang kuat akan mempunyai banyak energy untuk melakukan kegiatan belajar. Hasil belajar akan optimal kalau ada motivasi. Semakin tepat motivasi yang diberikan maka akan semakin belajar pula pelajaran itu.

Meskipun para ahli mendefinisikan dengan cara lain gaya yang berbeda, namun esensinya menuju kepada maksud yang sama, ialah bahwa motivasi itu merupakan:

1. Suatu kekuatan (power) atau tenaga (forces) atau daya (energy); atau

2. suatu keadaan yang kompleks (a complex state) dan kesiapsediaan (preparatory set) dalam diri individu (organism) untuk bergerak (to move, motion, motive) kearah tuntutan tertentu, baik disadari maupun tidak disadari.

Motivasi tersebut timbul dan tumbuh berkembang dengan jalan;

(1) Datang dari dalam diri individu itu sendiri (instrinsik); dan

(2) Datang dari lingkungan (ektrinsik)

(Syamsuddin Makmun,2005:37)
Berdasarkan konsep motivasi dari beberapa teori di atas, maka motivasi belajar dirumuskan sebagai kecenderungan peserta didik mengembangkan diri, dengan melakukan kegiatan belajar yang didukung oleh hasrat yang kuat untuk mencapai prestasi sebaik mungkin. Dan harus memperhatikan indicator motivasi sebagai berikut: 1) harapan sukses, 2) kerja keras, 3) tanggung jawab dan disiplin, 4) kemandirian dalam bertindak, 5) berani mengambil resiko, dan, 6) berusaha mencari cara-cara baru dalam memecahkan masalah sehingga akan meningkatkan keefektifitasan kondisi belajar.

Dalam kegiatan belajar mengajar, apabila ada seorang peserta didik, misalnya tidak berbuat sesuatu yang seharusnya dikerjakan, maka perlu diselidiki sebab-sebabnya.Sebabsebab itu biasanya bermacam-macam, mungkin iya tidak senang, mungkin sakit, lapar, ada problem pribadi dan lain-lain.Hal ini berarti pada diri anak tidak terjadi perubahan energy, tidak terangsang efeksinya untuk melakukan sesuatu, karena tidak memiliki tujuan atau kebutuhan belajar.Keadaan semacam ini perlu dilakukan daya upaya yang dapat menemukan sebab musababnya dan kemudian mendorong seorang peserta didik itu mau melakukan pekerjaan yang seharusnya dilakukan, yakni belajar. Dengan kata lainpeserta didik itu perlu diberikan rangsangan agar tumbuh motivasi pada dirinya. Atau singkatnya perlu diberikan motivasi. (Sudirman:1996:74-75)

\section{Hasil belajar}

Mukhtar (2003:54) mengatakan bahwa pengertian hasil belajar tidak dapat dipisahkan dan apa yang terjadi dalam aktifitas pembelajaran baik di kelas maupun diluar kelas. Apa yang dialami oleh peserta didik dalam proses pengembangan kemampuannya merupakan apa yang diperoleh dalam belajar dan pengalaman tersebut pada akhirnya dipengaruhi oleh beberapa faktor diantaranya keadaan kognitif, afektif dan psikomotornya pada waktu belajar. Kualitas pengajaran yang diterimanya dan cara pengelolaan proses interaksi yang dilakukan oleh guru.

Pakar pendidikan lain mendefinisikan bahwa yang dimaksud hasil belajar adalah perubahan perilaku secara keseluruhan bukan 
salah satu aspek potensi kemanusiaan saja (Supriyono, 2009:19). Berbeda dengan pendapatnya Bloom (Dalam Sumiati danAska, 2008).Hasil belajar mencakup kemampuan kognitif, afektif, dan psikomotorik. Jadi pendapat ini mengisyaratkan bahwa haasil belajar peserta didik harus diukur dengan tes tertulis, tes sikap, dan kemampuan skil secara nyata selama proses pembelajaran di kelas senyatanya.

Dalam penelitian ini yang dimaksud dengan hasil belajar adalah nilai tugas dan tes ulangan harian yang dilaksanakan secara tertulis pada akhir pembelajaran dan nilai hasil diskusi kelompok yang dinilai secara perorangan.

\section{Pendekatan}

Pendekatan dalam pembelajaran adalah peserta didik/peserta yang aktif.Titik tolak pemikiran bahwa peserta didik diajar dan guru mengajar beralih kepandangan bahwa peserta didik belajar, peserta didik mempelajari beberapa hal yang terus menerus dalam perjalanan hidupnya (Sumiati dan Aska, 2008:8).Dalam praktiknya pendekatan ini selalu disandingkan dengan pembelajaran yang konstektual. Dengan pembelajaran ini peserta didikakan memperoleh pengalaman belajar yang mengesankan dan akan diabadikan dalam kehidupan sebagai sosok yang demokratis, berfikir kreatif, yang selalu mengedapkan nilai-nilai kekeluargaan dan kegotongroyongan.

Pembelajaran dengan pendekatan saintifik adalah pembelajaran yang terdiri atas kegiatan mengamati (untuk mengidentifikasi hal-hal yang ingin diketahui), merumuskan pertanyaan (dan merumuskan hipotesis), mencoba/mengumpulkan data (informasi) dengan berbagai teknik, mengasosiasi/ menganalisis/mengolah data (informasi) dan menarik kesimpulan serta mengkomunikasikan hasil yang terdiri dari kesimpulan untuk memperoleh pengetahuan, keterampilan dan sikap. Langkah-langkah tersebut dapat dilanjutkan dengan kegiatan mencipta.Kurikulum 2013 mengembangkan sikap spiritual, sikap sosial, pengetahuan, dan keterampilan peserta didik. (Permendikbud Nomor 54/2013) Bagaimana Kurikulum 2013 memfasilitasi peserta didik memperoleh nilainilai, pengetahuan, dan keterampilan secara berimbang?, bagaimana proses pembelajaran dilaksanakan?

\section{Strategi Discovery Learning}

Strategi discovery learning adalah teori belajar yang didefinisikan sebagai proses pembelajaran yang terjadi bila pelajar tidak disajikan dengan pelajaran dalam bentuk finalnya, tetapi diharapkan mengorganisasi sendiri.

Discovery terjadi bila individu terlibat, terutama dalam penggunaan proses mentalnya untuk menemukan beberapa konsep dan prinsip.Discovery dilakukan melalui observasi, klasifikasi, pengukuran, prediksi, penentuan dan inferi.Discovery learning merupakan pembentukan kategori-kategori atau konsep-konsep, yang dapat memungkinkan terjadinya generalisasi.

Peserta didik dikatakan memahami suatu konsep apabila mengetahui lima unsur dari konsep itu, meliputi: 1) Nama; 2) Contohcontoh baik yang positif maupun yang negatif; 3) Karakteristik, baik yang pokok maupun tidak; 4) Rentangan karakteristik; 5) Kaidah

\section{- Langkah-langkah Operasional Implementasi Discovery Learning Langkah Persiapan}

1. Menentukan tujuan pembelajaran

2. Melakukan identifikasi karakteristik peserta didik (kemampuan awal, minat, gaya belajar, dan sebagainya)

3. Memilih materi pelajaran.

4. Menentukan topik-topik yang harus dipelajari peserta didik secara induktif (dari contoh-contoh generalisasi)

5. Mengembangkan bahan-bahan belajar yang berupa contoh-contoh, ilustrasi, tugas dan sebagainya untuk dipelajari peserta didik

6. Mengatur topik-topik pelajaran dari yang sederhana ke kompleks, dari yang konkret ke abstrak, atau dari tahap enaktif, ikonik sampai ke simbolik

7. Melakukan penilaian proses dan hasil belajar peserta didik

\section{Kerangka Konseptual}

Kerangka konseptual ini menggambarkan hubungan antara variabel 
tindakan dan variabel harapan.Variabel tindakan yaitu mengoptimalkan penerapan pendekatan saintifik model discoveri learning, sedangkan variabel harapan adalah meningkatkan motivasi dan hasil belajar.

\section{Hipotesis Tindakan}

"Jika penerapan Model discovery learning dilaksanakan secara optimal maka motivasi dan hasil belajar IPS peserta didik kelas VIICSemester duatahun pelajaran 2018/2019 dapat ditingkatkan".

\section{PROSEDUR PENELITIAN}

\section{Setting Penelitian}

Penelitian tindakan kelas (PTK) ini akan dilaksanakan di kelas VII-C SMP Negeri 9 MataramSemester duatahun pelajaran 2018/2019, dengan jumlah peserta didik sebanyak 31 orang.

\section{Faktor yang Diteliti}

1. Faktor Guru: yaitu dengan mengganti cara guru membuat Rencana Pelaksanaan Pembelajaran (RPP) dan pelaksanaannya dalam pembelajaran di kelas senyatanya dengan menerapkan pendekatan saintifikmodel discovery learning dalam upaya meningkatkan motivasi dan hasil belajar IPS peserta didikKelas VII-C SMP Negeri 9 Mataram.

2. Faktor Peserta Didik: yaitu peningkatan motivasi dan hasil belajar yang terlihat pada perilaku peserta didik selama diskusi kelompok, yang berdampak pada peningkatan motivasi dan hasil belajar IPS peserta didik Kelas VII-C Semester duaTahun pelajaran 2018/2019 di SMP Negeri 9 Mataram.

\section{Rencana Tindakan}

kegiatan nyata di kelas VII-C yaitu melaksanakan proses pembelajaran dengan menerapkan model discovery learning dalam upaya meningkatan motivasi dan hasil belajar IPSpeserta didik kelas VII.2SMP Negeri 9 MataramSemester duatahun pelajaran $2018 / 2019$. Tindakan nyata yang dilakukan oleh guru selaku peneliti adalah dengan menggunakan siklus.Gambaran siklus dalam penelitian ini adalah sebagai berikut:

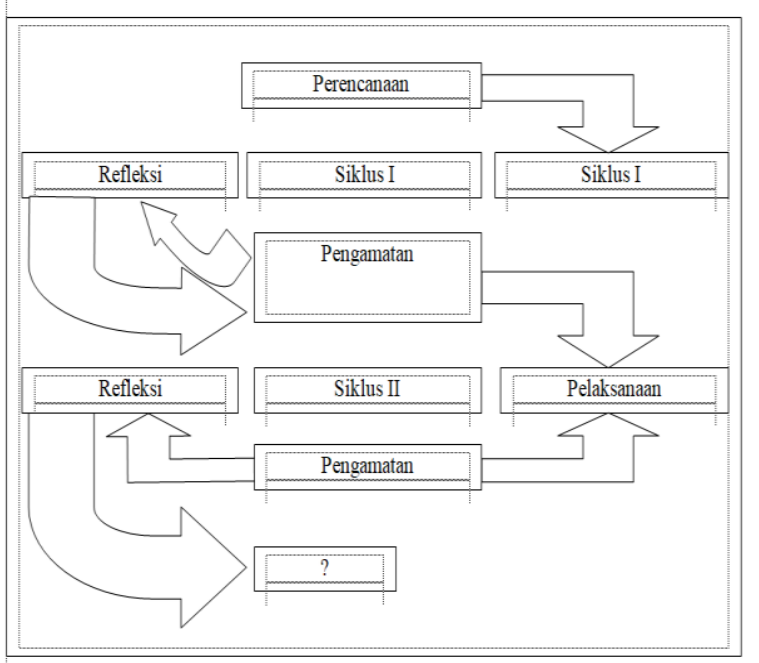

Setiap siklus selama penelitian ini berisi 4 (empat) tahapan yaitu: 1) Perencanaan (Planning), 2) Pelaksanaan (Action), 3) Observasi (Observation), dan 4) Refleksi (Reflection).

\section{Siklus Tindakan \\ SIKLUS I}

\section{Tahap Perencanaan (Planning)}

1. Menyusun Rencana Pelaksanaan Pembelajaran (RPP) dengan skenario sesuai dengan aturan main model pembelajaran saintifikmodel discovery learning

2. Menyiapkan sumber, bahan, dan semua alat yang digunakan dalam penelitian.

3. Menyusun/membuat lembar observasi guru dan lembar observasi peserta didik.

4. Menyusun alat evaluasi.

\section{Tahap Pelaksanaan (Action)}

\section{Pertemuan I}

1. Guru membagi peserta didik menjadi 8 (delapan) kelompok kecil, masing-masing kelompok beranggotakan 3-4 orang peserta didik.

2. Masing-masing kelompok diberikan tugas/soal untuk dipecahkan bersama dalam kelompok, selanjutnya guru berkeliling untuk membimbing kelompok utamanya yang mengalami kesulitan/permasalahan.

\section{Pertemuan II}

1. Masing-masing kelompok maju kedepan untuk mempresentasikan hasil kerja kelompok secara bergiliran.

2. Tes tertulis

\section{Tahap Observasi (Observation)}

1. Observasi guru : 
Dilakukan oleh pengawas mata pelajaran IPS observer sekaligus sebagai pembimbing guru dalam melaksanakan Penelitian Tindakan Kelas (PTK).

2. Observasi Peserta Didik :

Dilaksanakan oleh guru mata pelajaran sekaligus sebagai peneliti dalam Penelitian Tindakan Kelas (PTK) pada kegiatan diskusi kelompok.

\section{Tahap Refleksi (Reflection)}

1. Renungan hasil perolehan data

2. Pengolahan dan analisa data hasil penelitian

3. Mencocokkan hasil analisa data dengan indikator keberhasilan

4. Rencana perbaikan dan tindak lanjut

\section{SIKLUS II}

Pada siklus ini semua kegiatan dan tahapan selama penelitian adalah sama, sifatnya mengulang dan memperbaiki terhadap tindakan yang masih memerlukan penyempurnaan dan pembenaran sebagaimana mestinya.

\section{Data dan Cara Pengambilannya.}

\section{Sumber Data}

Yang menjadi sumber data dalam penelitian tindakan kelas (PTK) ini adalah semua peserta didikkelas VII-CSemester duatahun pelajaran 2018/2019 di SMP Negeri 9 Mataram dan peneliti.

\section{Jenis Data}

- Jenis data yang berasal dari guru selaku peneliti

1). Data tentang Rencana Pelaksanaan Pembelajaran (RPP)

2). Data Pelaksanaan Pembelajaran

- Jenis data yang berasal dari peserta didik :

1). Data kemajuan motivasi belajar

2). Data hasil diskusi kelompok

3). Data hasil belajar

Cara Pengambilan data

- Data kegiatan pembelajaran diambil dari RPP yang dibuat oleh guru dan lembar observasi pelaksanaan metode pembelajaran model discovery learning

- Data kemajuan motivasi belajar; diambil dari lembar observasi selama diskusi kelompok.

- Data kemajuan hasil belajar; diambil dari laporan individu hasil diskusi kelompok dan hasil tes tertulis yang dilaksanakan pada akhir proses pembelajaran

\section{Indikator Keberhasilan dan Teknik analisa} data

\section{Teknik analisa data}

Untuk menganalisis data akan dilakukan melalui analisis deskriptif kuantitatif melalui pendataan, analisis dan pembahasan terhadap data yang diperoleh dengan mencocokkan tingkat keoptimalan terhadap capaian indikator keberhasilan yang ada.

\section{Indikator Keberhasilan}

1. guru telah dinyatakan berhasil melaksanakan proses pembelajaran dengan pendekatan saintifik model discovery learning, bila telah mencapai skor rata-rata $\geq 4,00$ (kategori baik)

2. Motivasi belajar IPS peserta didik kelas VII-C dinyatakan telah meningkat jika $85 \%$ dari jumlah peserta didik telah memperoleh skor rata-rata $\geq 4,0$ dan hasil belajar dinyatakan telah meningkat jika $85 \%$ dari jumlah peserta didik memperoleh nilai rata-rata $\geq 75,00$ (sesuai KKM).

\section{HASIL PENELITIAN \\ DESKRIPSI SIKLUS I}

\section{Tahap Perencanaan}

Pada tahapan ini yang telah dilakukan oleh guru selaku peneliti adalah; 1) menyusun RPP dengan skenario pembelajaran discovery learning, 2) telah berhasil menyiapkan alat, sumber, bahan yang diperlukan dalam penelitian, 3) berhasil menyusun instrument observasi guru dan instrument observasi peserta didik, dan 4) menyusun alat evaluasi.

\section{Tahap Pelaksanaan}

Pertemuan Pertama:

1. Guru menyampaikan materi pelajaran dengan pendekatan saintifik dengan kegiatan mengamati dan menanya

2. Peserta didik dibagi menjadi 7 kelompok kecil yang anggotanya $4-5$ orang peserta didik secara heterogen

3. Peserta didik berdiskusi dengan model discovery learning dengan kegiatan pokoknya memecahkan persoalan/soalsoal yang menjadi tanggung jawabnya.

4. Selama peserta didik berdiskusi, guru berkeliling membimbing kelompok 
sekaligus

melakukan

observasi/pengamatan terhadap aspekaspek yang telah direncanakan.

Pertemuan kedua

1. Masing-masing kelompok secara bergiliran mempresentasikan di depan kelas yang diikuti oleh semua anggota kelompok.

2. Guru mengamati/mengobservasi ketrampilan peserta didik selama persentasi sesuai dengan aspek pengamatan ketrampilan yang telah di rencanakan.

3. Tes tertulis

\section{Tahap Observasi}

Observasi guru memperoleh skor ratarata sebesar 3,07 dan 3,29, observasi peserta didik memperoleh skor rata-rata sebesar 3,34 dan 3,58. Dan hasil belajar peserta didik memperoleh nilai rata-rata dari tugas dan tes tertulis sebesar 59,68 dan 60,39

\section{Tahap Refleksi}

1. Renungan data hasil perolehan data pada siklus I

2. Pengolahan data hasil observasi guru, peserta didik dan tes tertulis.

3. Mencocokkan hasil yang ada dengan Indikator keberhasilan.

4. Merencanakan perbaikan terhadap jenis tindakan yang menyebabkan belum tuntas Indikator keberhasilan. Oleh karena Indikator keberhasilan belum terbukti maka penelitian dilanjutkan ke siklus II.

\section{DESKRIPSI SIKLUS II \\ Tahap Perencanaan}

Pada tahapan ini jenis kegiatan yang dilakukan masih mengacu pada kegiatan siklus I, bedanya hanya terjadi perbaikan seperlunya yaitu: 1) penyusunan RPP dengan mengacu pada pendekatan saintifik model discovery learning dan diskusi kelompok dan penyempurnaan pada bagian skenario pembelajaran, 2) menyiapkan alat, sumber, bahan yang diperlukan dalam proses tindakan dikelas senyatanyan, 3) menyiapkan lembar observasi guru dan lembar observasi peserta didik sebagaimana pada siklus I, 4) menyiapkan alat evaluasi sebagaimana yang telah dibuat pada siklus I.

\section{Tahap Pelaksanaan}

Secara umum tahapan pelaksanaan proses pembelajaran pada siklus II ini masih mengacu pada pelaksanaan proses pembelajaran sebelumnya. Pemecahan yang dilakukan pada proses pembelajaran ini adalah: 1) pelaksanaan proses diskusi kelompok kecil lebih dioptimalkan, 2) pelaksanaan pembimbingan kelompok sekaligus observasi peserta didik lebih di efektifkan. Utamanya pengamatan peserta didik yang aktif, yang kurang aktif, peserta didik yang tidak aktif, dengan harapan proses analisa data lebih signifikan, 3)laporan hasil kerja kelompok yang dibuat secara individu yang dipresentasikan dikelas difokuskan, dan 4) pelaksanaan tes tertulis sebagai perwujudan dari peningkatan hasil belajar peserta didik lebih diperketat.

\section{Tahap Observasi}

Observasi guru memperoleh skor rata-rata sebesar 4,36 dan 4,79, observasi peserta didik memperoleh skor rata-rata sebesar 4,17 dan 4,38. Dan hasil belajar peserta didik memperoleh nilai rata-rata dari tugas dan tes tertulis sebesar 96,77 dan 87,87

\section{Tahap Refleksi}

1. Renungan atas perolehan data hasil observasi guru, observasi peserta didik, dan hasil tes tertulis sebagai wujud dari peningkatan motivasi dan hasil belajar peserta didik di kelas senyatanya.

2. Pengolahan data hasil observasi guru, observasi peserta didik, presentasi peserta didik dan tes tertulis

3. Mencocokkan perolehan data hasil tindakan dengan Indikator keberhasilan yang telah ditetapkan.

4. Guru memberikan hadiah/reward kepada semua peserta didikkelas VII-C atas keberhasilannya dalam upaya meningkatkan motivasi belajar yang berdampak terhadap perolehan hasil belajar sesuai dengan KKM yang telah ditetapkan.

\section{PEMBAHASAN \\ SIKLUS I}

\section{Tahap Perencanaan}

Peneliti menyusun RPP dengan skenario penerapan pendekatan Saintifik model Discovery Learning, menyiapkan alat, sumber, bahan yang diperlukan dalam proses 
pembelajaran, menyiapkan instrument observasi guru maupun instrument observasi peserta didik. Ada kendala yang dihadapi selama persiapan alat dan bahan pembelajaran, tetapi setelah meminta petunjuk kepada pembimbing kendala yang dihadapi pun dapat diatasi dengan baik.

\section{Tahap Pelaksanaan}

a. Mengamati

- Guru menugaskan kepada peserta didik secara berkelompok untuk menggali informasi dari buku paket tentang materi pelajaran yang disajikan.

- Guru menjelaskan materi pelajaran dan memberikan contoh konkrit yang bisa dimengerti oleh peserta didik

b. Menanya

- Guru memberikan trik-trik kepada peserta didik tentang tata cara bertanya yang baik dan benar sesuai dengan materi pelajaran yang sedang disajikan.

- Peserta didik secara teratur bertanya tentang hal-hal yang belum dimengerti sesuai materi yang sedang dipelajari.

c. Mencoba (mengumpulkan data/informasi)

- Secara berkelompok peserta didik mendiskusikan masalah yang menjadi tanggung jawabnya.

- Melakukan eksperimen dalam kelompok terhaadap permasalahan yang sedang di diskusikan

- Mengumpulkan data yang berasal dari semua anggota kelompok

d. Mengasosiasikan/mengolah informasi

- Semua anggota kelompok menjawab dan menelaah semua jawaban yang telah di diskusikan bersama

- Hasil jawaban di analisis bersama untuk bisa di paparkan di depan kelas pada saat menyampaikan informasi

- Kelompok membuat kesepakatan akhir dari hasil diskusi kelompok

e. Mengkomunikasikan

1. Guru kembali menyampaikan uraian materi pelajaran terkait dengan hasil kegiatan mengamati, menanya, mencoba, dan mengolah informasi.

2. Guru mempersilahkan kepada semua anggota kelompok untuk menginformaasikan hasil kerja kelompoknya.

3. Semua peserta didik secara berkelompok menanggapi setiap paparan dari kelompok lain

4. Peserta didik dengan bimbingan guru membuat kesimpulan bersama dari seluruh permasalahan/soal yang menjadi tanggung jawabnya.

5. Tes tertulis.

\section{Tahap Observasi}

Observasi guru pertemuan I memperoleh skor rata-rata 3,07 dan pertemuan II memperoleh skor rata-rata 3,29, Hasil observasi peserta didik dalam upaya peningkatan motivasi dan hasil belajar IPSpeserta didikkelas VII-CSemester duatahun pelajaran 2018/2019 di SMP Negeri 9 Mataram diperoleh skor rata-rata pertemuan I $(3,34)$ dan pertemuan II $(3,58)$. Dari hasil tugas dan tes tertulis yang materinya hanya sekitar yang diajarkan pada saat itu juga, diperoleh nilai rata-rata $(59,68)$ dan $(60,39)$ kategori cukup.

\section{Tahap Refleksi}

Hasil analisa data peningkatan motivasi belajar pada siklus I ini $(3,46)$ sedangkan yang diminta dalam Indikator keberhasilan $(\geq$ $4,0)$, ini artinya belum berhasil.

Karena Indikator keberhasilan belum tercapai, penelitian tindakan kelas (PTK) dilanjutkan ke siklus II dengan harapan optimalisasi penerapan strategi pembelajaran dengan pendekatan saintifik model discovery learning dapat meningkatkan motivasi belajar IPSpeserta didikkelas VII-C Semester duatahun pelajaran 2018/2019 di SMP Negeri 9 Mataram.

\section{SIKLUS II}

\section{Tahap Perencanaan}

Peneliti menyusun Rencana Pelaksanaan Pembelajaran (RPP) dengan memperhatikan kesalahan-kesalahan pada siklus I. peneliti lebih memfokuskan tentang Rencana strategi jitu sehingga proses pembelajaran dengan pendekatan Saintifik model Discovery Learning dapat terelaisasi dengan baik, karenanya dalam penyusunan skenario benar-benar dirinci dari tiap aspek pada proses pembelajaran dengan model Discovery Learning. 
Sebelum proses pembelajaran dilaksanakan, peneliti menyiapkan semua alat, bahan, dan segala sesuatunya sehingga dalam pelaksanaan proses pembelajaran berjalan sesuai dengan skenario yang telah direncanakan. Agar proses pembelajaran dapat teratasi maka peneliti juga menyiapkan lembar observasi guru dan lembar observasi peserta didik sebagai tolak ukur ketercapaian peningkatan motivasi dan hasil belajar IPSpeserta didikkelas VII-CSMP Negeri 9 Mataram.

\section{Tahap Pelaksanaan}

Pada tahap pelaksanaan di siklus II ini pada dasarnya masih mengacu pada pelaksanaan siklus I, yaitu penerapan pendekatan Saintifik model Discovery Learning dan. Bedanya pada siklus ini lebih dioptimalkan.

\section{Tahap Observasi}

Pada siklus II ini hasil observasi pertemuan pertama skor rata-rata $(4,36)$ dan pertemuan kedua $(4,79)$, Upaya meningkatkan motivasi belajar IPSpeserta didikkelas VII-C Semester duatahun pelajaran 2018/2019 di SMP Negeri 9 Mataram pada pertemuan I diperoleh skor rata-rata $(4,17)$ dan pertemuan II $(4,38)$, Dampak nyata dari meningkatnya motivasi belajar adalah hasil belajar juga meningkat, dari data hasil perolehan nilai rata-rata tugas dan tes tertulis adalah $(96,77)$ dan $(87,87)$ sementara pada siklus sebelumnya hanya $(59,68)$ dan $(60,39)$ berarti mengalami peningkatan yang signifikan.

\section{Tahap Refleksi}

Hasil analisa data peningkatan motivasi dan hasil belajar peserta didik pada siklus II adalah $(4,27)$ dan $(92,32)$ sedangkan Indikator keberhasilan $(\geq 4,0)$ dan $\geq 75,00$. Ini artinya pada siklus II hasilnya telah melampaui Indikator keberhasilan yang telah di tetapkan.

Karena Indikator keberhasilan telah terbukti, maka tidak perlu ada upaya perbaikan dan penyempurnaan. Pendekatan Saintifik model Discovery Learning telah mampu meningkatkan motivasi dan hasil belajar peserta didik yang ditandai dengan tercapainya Indikator keberhasilan dan terjadinya peningkatan hasil belajar peserta didik. "Penelitian Tindakan Kelas (PTK) dihentikan pada siklus II dengan hasil memuaskan."

\section{SIMPULAN}

Data komulatif dari hasil penelitian tindakan kelas (PTK) dari siklus I ke Siklus II adalah sebagai berikut:

\begin{tabular}{|c|c|c|c|c|c|c|c|}
\hline \multirow{2}{*}{$\mathrm{N}_{0}$} & \multirow{2}{*}{ Jenis Kegiatan } & \multirow{2}{*}{$\begin{array}{l}\text { Indikator } \\
\text { keberhasilan }\end{array}$} & \multicolumn{2}{|c|}{ Siklus I } & \multicolumn{2}{|c|}{ Siklus II } & \multirow[t]{2}{*}{ Keterangan } \\
\hline & & & I & II & I & II & \\
\hline 1. & Observasi Guru & $\geq 4,00$ & 3,07 & 3,29 & 4,36 & 4,79 & Meningkat \\
\hline 2. & Observasi Peserta didik & $\geq 4,00$ & 3,34 & 3,58 & 4,17 & 4,38 & Meningkat \\
\hline 3. & Tugas & $\geq 75,00$ & 59,6 & & 96, & & Meningkat \\
\hline 4. & Tes tertulis & $\geq 75,00$ & 60,3 & & 87, & & Meningkat \\
\hline
\end{tabular}

Penerapan pendekatan Saintifik model Discovery Learning sangat efektif upaya untuk meningkatkan motivasi dan hasil belajar IPSpeserta didikkelas VII-CSemester duatahun pelajaran 2018/2019 di SMP Negeri 9 Mataram. Fakta telah menunjukkan perolehan rata-rata skor motivasi belajar peserta didik pada siklus I ke siklus II sudah melampaui Indikator keberhasilan yang ditetapkan.Penelitian dinyatakan "berhasil" dan dihentikan pada siklus II.

\section{SARAN}

Disarankan kepada guru sejawat untuk melaksanakan Penelitian Tindakan Kelas (PTK) dalam upaya untuk meningkatkan motivasi dan hasil belajar peserta didik sesuai dengan mata pelajaran masing-masing.

Disarankan kepada para semua peserta didikkelas VII-CSMP Negeri 9 Mataram untuk membiasakan belajar dengan pendekatan yang kontekstual utamanya strategi yang mampu membangkitkan motivasi belajar peserta didik yang dampaknya hasil belajar dapat ditingkatkan seperti yang diharapkan.

\section{DAFTAR PUSTAKA}

Anonim, 2019, dalam

http://dadangjsn.blogspot.com/2014/0

6/pengertiandefinisi-pendekatansaintifik.html, Tanggal 19 Januari 2019, Pukul 20.35 Wita

Arikunto, s. 2009, Penelitian Tindakan Kelas, Jakarta : Bumi Aksara.

Harun Rasyid dan Mansur, 2008, Penilaian Hasil Belajar, Bandung : CV Wacana Prima. 
Lukmanul A, 2008, Perencanaan Pembelajaran, Bandung : CV Wacana Prima.

Mukhtar, 2003, Prosedur Penilaian, Jakarta : Rineka Cipta.

Nurhadi, 2003, Yasin ,B dan Sendule.A, 2003, Kontekstual dan Penerapannya dalam KBK, Malang : Unitipetas Negeri Malang.

Permen 81A Tahun 2013 Tentang Implementasi Kurikulum 2013

Robert E Slavin, 2010, Cooperative Learning Teori, riset dan Praktik, Bandung : Nusa Media.

Sardiman, 2007, Indikator Dan Motivasi Belajar Mengajar, Jakarta : Raja Grafindo Perkasa.

Supriono, 2009, Cooperative Learning Teori dan Aplikasi PAIKEM, Yogyakarta : Pustaka Pelajar.

Syahrir, S., \& Susilawati, S. (2015). Pengembangan Modul Pembelajaran Matematika Siswa SMP. Jurnal Ilmiah Mandala Education (JIME), 1(2), 162-171. 